\title{
Application of a Method for Intelligent Multi-Criteria Analysis of the Environmental Impact of Tailing Ponds in Northern Kosovo and Metohija
}

\author{
Gordana Milentijević ${ }^{1}$, Blagoje Nedeljković ${ }^{1}$, Milena Lekić ${ }^{2, *}$, Zoran Nikić ${ }^{3}$, Ivica Ristović ${ }^{2}$ \\ and Jelena Djokić ${ }^{1}$ \\ 1 Faculty of Techinal Sciences, University of Pristina, 38220 Kosovska Mitrovica, Serbia; \\ gordanamilentijevic@yahoo.com (G.M.); blagojenedeljkovic@yahoo.com (B.N.); jeladjokic7@gmail.com (J.D.) \\ 2 Faculty of Mining and Geology, University of Belgrade, 11000 Belgrade, Serbia; ivica.ristovic@rgf.bg.ac.rs \\ 3 Faculty of Forestry, University of Belgrade, 11030 Belgrade, Serbia; zoran.nikic@sfb.bg.ac.rs \\ * Correspondence: milena.lekic@rgf.rs; Tel.: +381-11-3219-119 \\ Academic Editor: Enrico Sciubba \\ Received: 27 May 2016; Accepted: 3 November 2016; Published: 10 November 2016
}

\begin{abstract}
The technological process of exploitation of mineral resources and processing of mined ores to cater to the market results, among other things, in a large amount of tailings deposed on tailing ponds. Because of the chemical composition of the material, the increasing amount of waste, and the mismanagement of recovery and reclamation of ponds, these ponds have become a significant element of negative impact on the surrounding ecosystem. Economics was behind the discharging of this material, resulting in tailing ponds created in inappropriate areas. There is an ongoing process of depositing tailings on old tailing ponds, although no special attention has been paid to the subsequent effect on the environment. Application of intelligent multi-criteria analysis AHP and PROMETHEE has been performed in this paper for the purpose of ranking the degree of negative impact on the environment of tailing ponds. Analysis is performed for five tailing ponds of MMCC (Mining Metallurgy Chemical Combine) "Trepča", whereby two of the ponds are active and three inactive. The ponds are in relatively close proximity to the municipalities of Zvečan and Kosovska Mitrovica, to the north of Kosovo and Metohija, Republic of Serbia. In order to achieve the most objective results, the AHP and PROMETHEE methods were applied. By using these methods for calculations, the following ranking for the flotation tailing waste deposits was obtained, regarding their environmental impact: Žitkovac, Tvrđanski Do, Bostanište, Gornje Polje and Žarkov Potok. This result can contribute to the decision-making process of a prioritizing strategy for rehabilitation and remediation of these five flotation tailings. The analysis illustrates that application of intelligent multi-criteria analysis is a useful environmental management tool to be included in the decision-making process.
\end{abstract}

Keywords: tailing pond; environment; multi-criteria analysis; ecology; Trepča

\section{Introduction}

Mining presents a significant element of economic development in every state. It is also known that the biggest environmental pollutant is the mining sector [1]. Mining is followed by a mass production of waste in the form of tailing on tailing ponds. They are often formed in areas which have other potential (agriculture, water supply, urban areas, water flows, etc.). In general, all material left after the extraction of minerals or after the process of exploitation is waste, which when dumped on the deposit spot creates the tailing pond [2].

Vast areas are covered with mining tailings. For example, amounts of waste from mining in EU countries are around $400 \mathrm{Mt}$, and tailing waste is approximately $29 \%$ of total waste produced [3]. 
According to the "2012 Minerals Yearbook, Mining and quarrying trends (advance release)" published by the U.S. Department of the Interior, U.S. Geological Survey, in the U.S. total waste from mining and ore processing in 2012 was around 5210 million tons [4]. It is interesting that in the previous report, there was a conclusion of a "slight increase" of quantity of mining waste in 2012 compared to 2011.

According to the Environmental Protection Agency (2005) [5] in the "Report of the State of the Environment in Republic of Serbia", it is estimated that there are around 700 million tons of flotation and separation tailings, between 1.4 and 1.7 billion tons of tailing wastes from opening pits and around 170 million tons of ashes from thermal power plants on deposit spots and landfills in Serbia. Metallurgy in the Republic of Serbia contributes $10 \%$ to the total gross domestic product for production of basic metals and metal products [6].

In mines with metallic mineral ores, concentration of heavy metals in tailing has increased. This is why the problem of environmental protection is severe in systems like Mining Metallurgy Chemical Combine (MMCC) "Trepča”.

The purpose of this paper is to rank the flotation tailings of MMCC "Trepča" in terms of negative environmental impact. For these purposes, selection of relevant parameters was undertaken and calculations were made through the application of multi-criteria analysis (MCA). This method has recently been used in a variety of studies by numerous researchers deliberating different problems. In the field of mining, such researchers include Bogdanović et al. 2012 and Ataei et al. 2008 and in the area of environmental protection, Kiker et al. 2005 among others [7-9].

In this paper, analysis includes five non-remediated flotation tailings. On all five tailings, MMCC "Trepča" disposed their waste. Two flotation tailings are active (waste is still being disposed there) and three are passive, meaning there is no longer any dumping of waste.

\section{Study Area}

The study area is situated on the large highland Kosovo, to the north of the Autonomous Region Kosovo and Metohija (Figure 1). Administratively, it belongs to the municipalities of Zvečan and Kosovska Mitrovica. The study area has the typical continental climate with long and hot summers and cold winters. According to the meteorological station Kosovska Mitrovica, the average precipitation from 1991-2013 was $637 \mathrm{~mm}$, and average annual temperature $10.3^{\circ} \mathrm{C}$. Mean wind velocity for Kosovska Mitrovica is $1.9 \mathrm{~m} / \mathrm{s}$, and the most frequent blowing direction is north with an average velocity of $2.3 \mathrm{~m} / \mathrm{s}$ and a northwesterly wind with an average velocity of $2.1 \mathrm{~m} / \mathrm{s}$ [10].

MMCC "Trepča" has produced around 120,000 $t$ of raw lead, 100,000 $t$ refined lead, $100 \mathrm{t}$ of silver, 80,000 t electrolyte zinc, 140,000 $\mathrm{t}$ artificial fertilizer, 50,000 $\mathrm{t}$ super phosphate, and 30,000 $\mathrm{t}$ accumulators, while daily production in mines was up to 10,000 $t$ of mined ores. This was the case until two decades ago for this giant that was one of the biggest producers of lead, zinc, silver and gold in Europe in the period from 1965 to 1985 . It had up to 20 facilities and employed up to 25,000 workers at one period of time [11].

By mining in Kopaonik's metallogenic zone and flotation processing of metallic minerals, MMCC “Trepča” established tailing ponds: Žarkov Potok, Gornje Polje, Žitkovac, Tvrđanski Do and Bostanište. All five tailings are in an administrative unit of the Kosovska Mitrovica area and in the municipalities of Zvečan and Mitrovica. The tailings are polymetallic and their mineral compositions are mostly heavy metals, as they were extracted from ore. In the process of creation and expansion of these five tailing ponds, material was transported hydraulically and deposed physically by hydrocyclone.

The landscape where the tailings are situated is the Ibar River's alluvial plain [12]. Since the tailing deposits have not been rehabilitated, the material from the deposits have scattered over the years in the environment through the aeolian process, gravity and water flows. Tailing material from the analyzed deposits shows permanent toxic pollution of water and agricultural land [13]. All atmospheric water and waters from tailing ponds are released into the Ibar River through drainage systems in the tailings. The water bodies from the area as well as those from remote areas are highly endangered by the 
leaching contamination from the tailings. The characteristics of the analyzed flotation tailing waste deposits are shown in Table 1.

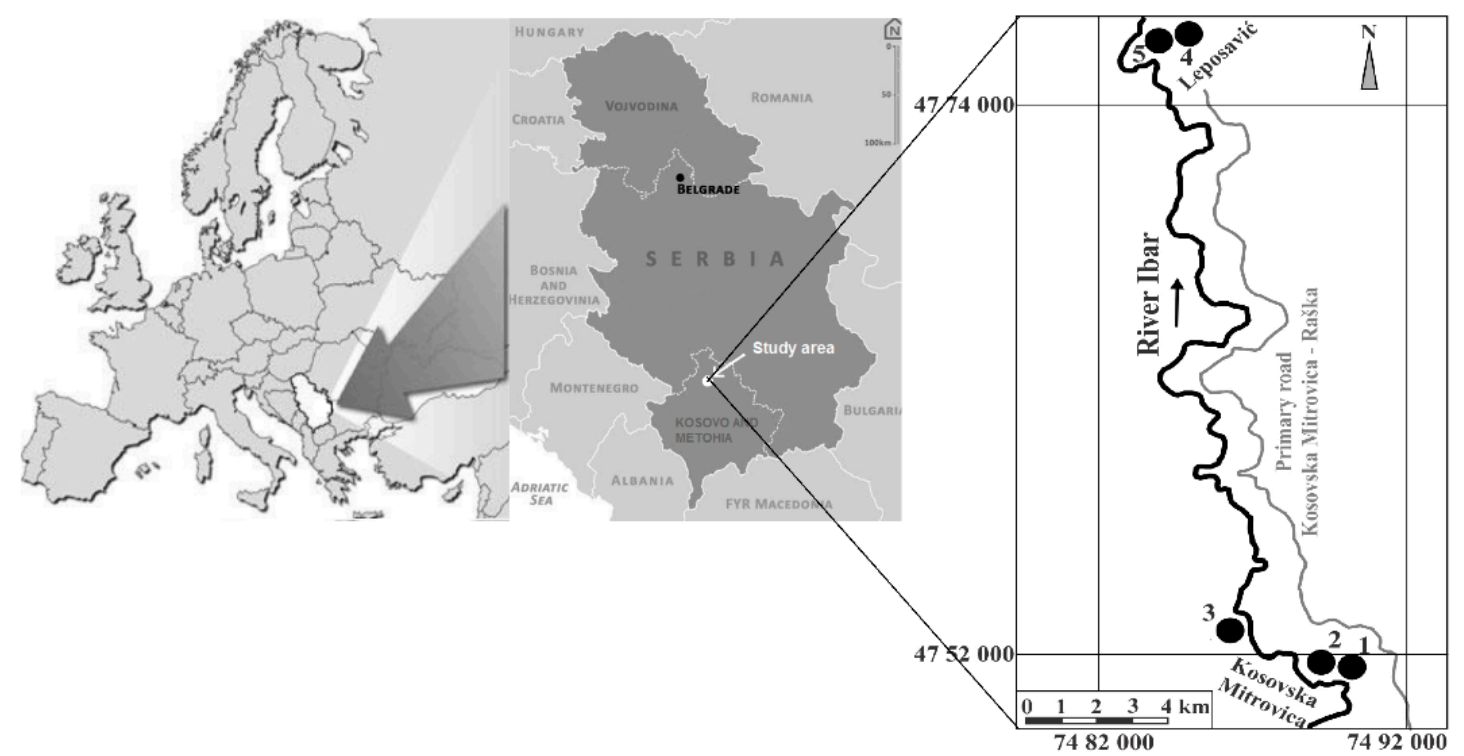

Figure 1. Schematic review of the study area. - - Tailing ponds: 1-Žarkov Potok; 2-Gornje Polje; 3-Žitkovac; 4-Bostanište; 5-Tvrđanski Do.

Table 1. The characteristics of the analyzed flotation tailing waste.

\begin{tabular}{|c|c|c|c|c|c|}
\hline $\begin{array}{ll}\text { Criteria } & \text { Tailing Ponds } \\
\end{array}$ & Žarkov Potok-A1 & Gornje Polje-A2 & Žitkovac-A3 & Tvrđanski Do-A4 & Bostanište-A5 \\
\hline $\begin{array}{l}\text { Vicinity of the water } \\
\text { source-C1 }\end{array}$ & No & $50 \mathrm{~m}$-wells & $50 \mathrm{~m}$-wells. & $12 \mathrm{~km}$-wells & $12 \mathrm{~km}$-wells \\
\hline $\begin{array}{l}\text { Vicinity of the } \\
\text { settlement-C2 }\end{array}$ & About $500 \mathrm{~m}$ & About $200 \mathrm{~m}$ & About $100 \mathrm{~m}$ & About $50 \mathrm{~m}$ & About $50 \mathrm{~m}$ \\
\hline $\begin{array}{l}\text { Vicinity of agricultural } \\
\text { area-C3 }\end{array}$ & About $500 \mathrm{~m}$ & About $200 \mathrm{~m}$ & About $50 \mathrm{~m}$ & About $50 \mathrm{~m}$ & About $50 \mathrm{~m}$ \\
\hline $\begin{array}{l}\text { Vicinity of permanent water } \\
\text { flow-C4 }\end{array}$ & About $100 \mathrm{~m}$, Ibar & About $50 \mathrm{~m}$. Ibar & $\begin{array}{l}\text { About } 50 \mathrm{~m} \\
\text { Ibar }\end{array}$ & About $50 \mathrm{~m}$, Ibar & $\begin{array}{l}\text { About } 70 \mathrm{~m}, \\
\text { Ibar }\end{array}$ \\
\hline $\begin{array}{l}\text { Quantity of deposited } \\
\text { material-C5 }\end{array}$ & $9,961,113 \mathrm{t}$ & $26,344,212 \mathrm{t}$ & $7,594,932 \mathrm{t}$ & $1,442,812 \mathrm{t}$ & $5,641,612 \mathrm{t}$ \\
\hline $\begin{array}{l}\text { Occurrence of the flooding } \\
\text { water sources-C6 }\end{array}$ & No & Yes & No & No & No \\
\hline Activity of the tailings-C7 & Active & Not active & Not active & Not active & Active \\
\hline \multirow{2}{*}{ Geological environment- $\mathrm{C} 8$} & Alluvial & Alluvial & Alluvial & Alluvial & Alluvial \\
\hline & $4 \mathrm{~m}$ & $4 \mathrm{~m}$ & $4 \mathrm{~m}$ & $4 \mathrm{~m}$ & $4 \mathrm{~m}$ \\
\hline $\begin{array}{l}\text { General slope of the } \\
\text { terrain-C9 }\end{array}$ & $8 \%$ & $0 \%$ & $0 \%$ & $7 \%$ & $8 \%$ \\
\hline Tailing maintenance $-\mathrm{C} 10$ & No maintenance & No maintenance & $\begin{array}{c}\text { No } \\
\text { maintenance }\end{array}$ & No maintenance & $\begin{array}{c}\text { No } \\
\text { maintenance }\end{array}$ \\
\hline
\end{tabular}

Flotation tailing pond Žarkov Potok is an active landfill site only $2 \mathrm{~km}$ northeast from Kosovska Mitrovica, in the basin of Žarkov Potok, right next to the Ibar River. It was formed in 1975 and contains tailings from flotation Prvi Tunel. The space for deposition was constructed by building a dam $87 \mathrm{~m}$ high and with a predicted capacity of 8.2 million cubic meters of tailings. Material from flotation to the tailing pond is transported through a hydraulic tunnel. The tailing pond is in the central part of the landfill. Reclamation of the landfill was never undertaken, so when there is windy weather, the effect of dust lifting occurs. There are two channels for drainage of atmospheric waters from the landfill, 
which are about $100 \mathrm{~m}$ and $200 \mathrm{~m}$ from the dam and which stop the breakthrough of water towards the dam and its erosion. The composition of the waste is changeable; depending on weather, there is separation of pyrite and pyrrhotite for sulphuric acid production. Cleared water from the tailing pond of the landfill through collectors was placed there when the landfill was constructed, releasing waste into the Ibar River. The tailings are still not managed properly [11].

Flotation landfill Gornje Polje (Figure 2a) is placed on the Ibar River bank, on the part of the terrain between Kosovska Mitrovica and Zvečan. On this landfill, flotation tailings from flotation in Zvečan have been deposed since the operation started in 1930 and lasted until it was closed in 1983. It is approximately 50 ha, and around 12 million cubic meters of tailings lie there. On the northern part of the landfill, tailings from the lead smelter have been disposed for a long time, so the landfill has taken on the form of a cone. Deep cuts have been created as a result of erosion on both sides of the dam, through which comes discharge of atmospheric waters from the landfill directly into the Ibar. Deposed flotation tailing is in general oxidized and solid [1].
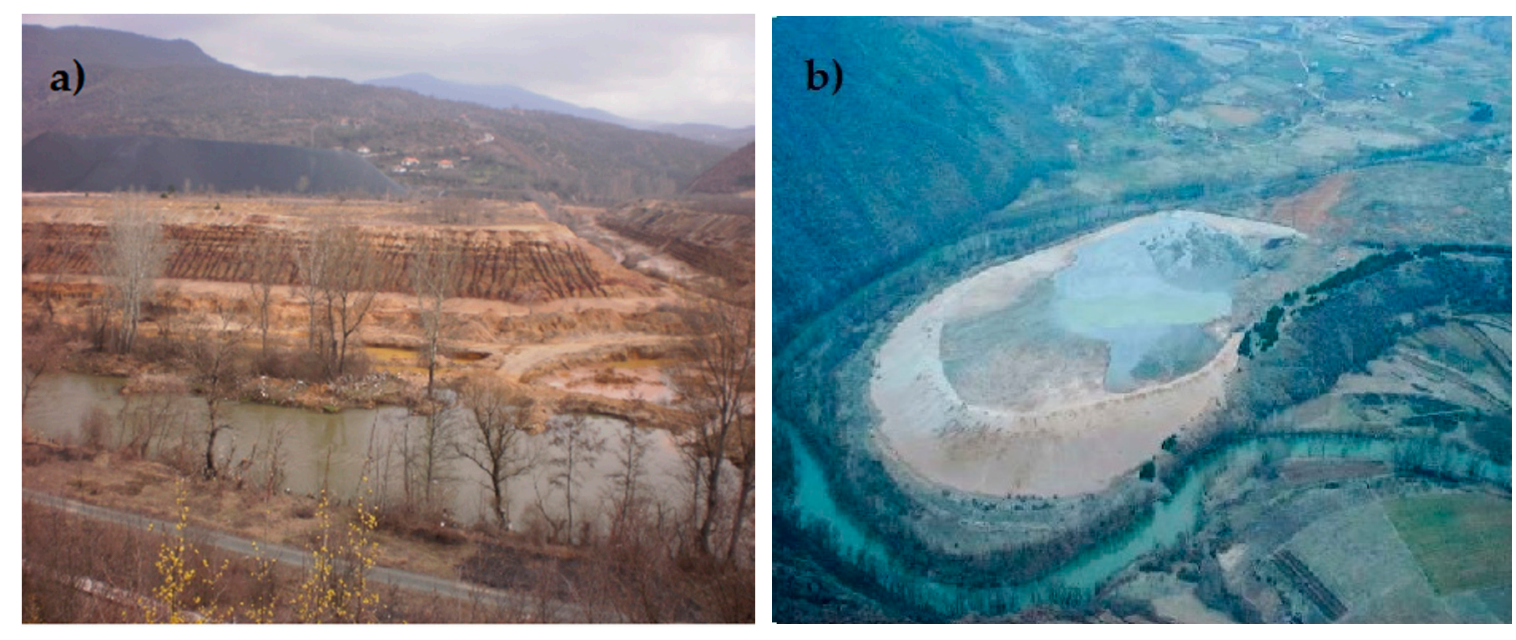

Figure 2. Tailing pond Gornje Polje (a)—not active; and tailing pond Bostanište (b) —active.

Flotation tailing Žitkovac is on the left side of the Ibar, in the village Žitkovac. Distance from tailings to settlement Zvečan is around $1 \mathrm{~km}$, and to Kosovska Mitrovica around $4 \mathrm{~km}$. The landfill was active from 1963 to 1974 . Flotation tailings are transported by hydraulics from flotation in Zvečan, where there are concentrations of lead and zinc ore from Stari Trg ore. The landfill surface is approximately $26 \mathrm{ha}$, and it is estimated that the amount of tailings dumped there is $7,500,000 \mathrm{~m}^{3}$ or around 3 million tons.

Flotation landfill Tvrđanski Do is east of regional road Kraljevo-Kosovska Mitrovica, in close proximity to the settlement Leposavić, on the right bank of the Ibar River. Flotation tailings from mines Belo Brdo, Crnac, Koporić, Žuta Prlina and Jelakce were deposed there. Surface of the landfill is around $7 \mathrm{ha}$ and on it are approximately 2,600,000 $\mathrm{t}$ of deposed tailings. The landfill dam has several steep slopes. Tailing is placed at the bottom of the slope, where there is a tree line next to the Ibar. The landfill was never reclaimed completely and, as a consequence, dust rises and endangers the Leposavić settlement whenever there is windy weather. Drainage water from the landfill is collected and taken directly into the Ibar. Surface of the tailing is oxidized and red. On the sides of the dam, solid parts are noticeable. Due to the fact that raising the upper level of the dam is no longer possible since its construction stability is in danger, there is further land filling with flotation tailing and a new tailing pond, Bostanište, has been established.

Landfill Bostanište (Figure $2 b$ ) is south of the landfill Tvrđanski Do and they are practically one landfill as the north part of the dam of the Bostanište landfill leans on the end of the dam of the older Tvrđanski Do landfill. Most of the Bostanište landfill is comprised of $1 \mathrm{~km}$ along Ibar River's bank. It is characterized by the steep slopes of the dam and has surfaces covered with sand; part of the slopes 
are oxidized tailings with deep erosive cuts. Remediation of the landfill has not been done and there is no plant cover, which causes rising dust, endangering the Leposavić settlement and surrounding villages. The landfill surface is cracked as a result of lack of water. Between landfill dam and the Ibar is a tree line with ground vegetation. Steep slopes of the landfill ravine are present as a result of erosion. Drainage of atmospheric waters, fallen off the surface of the landfill, is done by drainage pipes from main collectors on peripheral parts of the tailings.

The chemical composition of the tailing waste is shown for the flotation tailing waste Gornje Polje. The chemical composition is analyzed by the atomic absorption spectroscopy (AAS) method and the distribution maps are determined by scanning electron microscopy (SEM). The obtained results are presented in the Table 2 [14]. Mineralogy composition is determined by using X-ray diffractometry whereby the presence of quartz ankerite, pyrite and clay minerals are recorded. The chemical and mineralogy compositions for the water of four tailing waste deposits are similar [15].

Table 2. Chemical composition of the tailing waste deposits of Gornje Polje [16].

\begin{tabular}{|c|c|c|c|c|c|c|c|c|c|c|c|c|c|c|}
\hline \multirow{2}{*}{ Tailing Pond } & \multicolumn{14}{|c|}{ Element (\%) } \\
\hline & $\mathrm{O}$ & Al & $\mathrm{Si}$ & $S$ & $\mathrm{Ca}$ & $\mathrm{Fe}$ & $\mathrm{Zn}$ & As & Ag & $\mathrm{Cd}$ & $\mathrm{Sb}$ & $\mathrm{Hg}$ & $\mathrm{Pb}$ & Total \\
\hline Gornje Polje & 47.4 & 0.21 & 1.94 & 17.42 & 23.51 & 27.86 & 60.27 & 0.92 & 0.00 & 0.11 & 0.35 & 0.00 & 0.00 & 100.00 \\
\hline
\end{tabular}

The Ibar's water quality for 2008, on the sampling stations upstream and downstream from the flotation tailing waste deposit Bostanište, is presented in the following parameters: $\mathrm{pH}$, total solid particles, soluble matter, non-soluble particles, $\mathrm{SO}_{4}, \mathrm{~Pb}, \mathrm{Zn}, \mathrm{Cu}, \mathrm{Cd}, \mathrm{Fe}, \mathrm{Ca}$. The increased values of the elements in comparison to the maximum allowed concentrations according to the administrative decision to limit concentration of the pollutive matter (RS Official Gazette, No. 50/2012) [16] upstream from the deposit are determined only for lead in the range from 0.17 to $0.65 \mathrm{mg} / \mathrm{L}$ and iron from 0.15 to $4.12 \mathrm{mg} / \mathrm{L}$. Downstream from the deposit the values above the maximum allowed concentrations are recorded for lead in the range from 0.20 to $0.58 \mathrm{mg} / \mathrm{L}$, iron from 0.14 to $4.53 \mathrm{mg} / \mathrm{L}$ and copper from 0.02 to $0.12 \mathrm{mg} / \mathrm{L}$. The rest of the parameters have concentrations below the maximum allowed concentrations [17].

The heavy metal concentration in the top soil was examined in the area of the flotation tailing waste of Bostanište. The sampling was done to the north and the southeast of the deposit. In the northern direction, the top soil sampling was performed in the distances from the deposit of: $300 \mathrm{~m}$, $600 \mathrm{~m}$, and $800 \mathrm{~m}$; in the southeastern direction, the distance range was $150 \mathrm{~m}, 250 \mathrm{~m}, 350 \mathrm{~m}$ and $1400 \mathrm{~m}$. The analyses were conducted for the following heavy metals: $\mathrm{Mo}, \mathrm{Zr}, \mathrm{Sr}, \mathrm{Rb}, \mathrm{Pb}, \mathrm{Se}, \mathrm{As}, \mathrm{Hg}$, $\mathrm{Zn}, \mathrm{Cu}, \mathrm{Mi}, \mathrm{Co}, \mathrm{Fe}, \mathrm{Mn}, \mathrm{Cr}, \mathrm{Cd}$. Heavy metal concentration in the top soil in the area of Bostanište and their limited values according to the administrative decision on the soil quality (RS Official Gazette, No. 88/2010) [18], are shown in Table 3.

The mineral processing in MMCC “Trepča” is a metal concentration process. The ore is crushed, then milled to the average size of $0.1 \mathrm{~mm}$ in grain diameter. The grain-size distribution is of vital interest for the environmental impact assessment of the tailings. Based on the grain-size distribution investigation, done for the tailing waste Bostanište, the particles are sized between $0.1 \mathrm{~mm}$ and $0.2 \mathrm{~mm}$ diameter [19]. These results point to the fact that the particles can be driven by the wind and water in both the close and remote sampled distances. 
Table 3. Heavy metal concentration in the top soil in the area of Bostanište and their limited values [17].

\begin{tabular}{|c|c|c|c|c|c|c|c|c|}
\hline \multirow{2}{*}{$\begin{array}{l}\text { Element } \\
\mathrm{mg} / \mathrm{kg}\end{array}$} & \multicolumn{3}{|c|}{$\begin{array}{l}\text { In Northern Direction } \\
\text { from the Deposit }\end{array}$} & \multicolumn{4}{|c|}{ In Southeastern Direction from the Deposit } & \multirow{2}{*}{$\begin{array}{l}\text { Max. Allowed } \\
\text { Concentration * }\end{array}$} \\
\hline & $300 \mathrm{~m}$ & $600 \mathrm{~m}$ & $800 \mathrm{~m}$ & $150 \mathrm{~m}$ & $250 \mathrm{~m}$ & $350 \mathrm{~m}$ & $1400 \mathrm{~m}$ & \\
\hline Mo & - & - & - & - & - & - & - & 3 \\
\hline $\mathrm{Zr}$ & 246.50 & 263.75 & 118.05 & 173.82 & 255.64 & 205.16 & 107.94 & - \\
\hline $\mathrm{Sr}$ & 155.81 & 173.43 & 87.29 & 126.70 & 106.91 & 116.71 & 155.87 & - \\
\hline $\mathrm{Rb}$ & 68.45 & 85.01 & 40.91 & 52.05 & 57.01 & 52.37 & 77.48 & - \\
\hline $\mathrm{Pb}$ & 494.48 & 706.06 & 294.81 & $1,618,96$ & 532.04 & 607.74 & 563.48 & 85 \\
\hline Se & - & - & - & - & 1.08 & - & - & - \\
\hline As & 485.86 & 728.29 & 199.23 & $4,694,17$ & 722.96 & $1,040,84$ & 109.60 & 29 \\
\hline $\mathrm{Hg}$ & - & - & - & - & - & - & - & 0.3 \\
\hline $\mathrm{Zn}$ & 332.83 & 508.20 & 157.59 & 373.54 & 248.19 & 249.82 & 419.05 & 140 \\
\hline $\mathrm{Cu}$ & 106.54 & 19.65 & 90.43 & 50.88 & - & 17.96 & 61.91 & 36 \\
\hline $\mathrm{Ni}$ & 142.71 & 245.55 & 314.70 & 169.53 & 124.94 & 225.40 & 177.49 & 35 \\
\hline Co & - & - & - & - & 216.30 & - & - & 9 \\
\hline $\mathrm{Fe}$ & $48,292,43$ & $44,270,51$ & $48,230,73$ & $132,685,60$ & $37,965,80$ & $50,538,11$ & $43,713,16$ & - \\
\hline $\mathrm{Mn}$ & $2,046,80$ & 1,985,19 & $1,084,89$ & $1,996,50$ & $1,597,47$ & $1,078,89$ & $1,070,48$ & - \\
\hline $\mathrm{Cr}$ & 487.49 & 303.75 & 398.10 & $1,135,21$ & 355.87 & 509.12 & 249.59 & 100 \\
\hline $\mathrm{Cd}$ & 7.61 & 7.62 & 6.67 & 4.77 & 1.90 & 3.81 & 6.67 & 0.8 \\
\hline
\end{tabular}

limited values according to the administrative decision on the soil quality (RS Official Gazette, No. 88/2010) [18].

\section{Materials and Methods}

\subsection{Tailing Ponds}

The waste tailings from processing of flotation of metallic mineral ores are by-products of MMCC "Trepča" mining activities. Keeping in mind the topic of this paper-the physical and chemical characteristics of deposed material and the fact that tailings have not been remediated-the basic intention was to choose and apply a method with a high level of quality that combines and allows analysis of multiple elements. The method for ranking the effect of tailings on the surrounding ecosystem had to fulfil the following criteria: it should be in compliance with the concept of sustainable development; it should be in compliance with different cultural, social and organizational frameworks; it should be applicable to large and small companies and for large and small-scale environmental pollutants. It was thus decided that the ranking of five current tailing ponds should be done by multi-criteria analysis.

Field work and analysis of flotation tailings and surroundings was undertaken as part of the preparation. Data collection and analysis of documentation and published papers addressing the problem were done. The mapping of five tailings with waste from the flotation process is done through terrain research for: Žarkov Potok, Gornje Polje, Žitkovac, Tvrđanski Do and Bostanište. All five tailings are in an environment with agricultural, urban, recreational, cultural and other potential. All are in close proximity to water streams or on the banks of the Ibar. It should be noted that, besides problematic ownership, lack of data about the current conditions of the landfill, characteristics of the deposed material and environmental impact assessment analyses is also a concern.

Important environmental aspects (air, water, soil), character of deposed material (chemical, quantities and other), elements with special value in their environments (natural rarities, archaeological and religious sites, etc.), technical and sociological aspects as well as many others are included in the assessment of the tailing ponds' impact on the surrounding ecosystem.

\subsection{Statistical Analysis}

One of the advantages of MCA is its ability to help the researcher overcome doubts and problems in a consistent manner. Complexity of data in MCA is reflected in the large amount of data, different measuring units of some parameters, and different scales used to analyze the problem. These methods 
do not replace the decision-making process, but can contribute to understanding the deliberated multi-criteria problem [20].

The criteria selection for assessment is an important and very complex step, determining the final results of the MCA. The set criteria estimation result essentially depends on their weight factors. For coupling the weight factor to the selected criterion, it the mixed approach was applied, using subjective and objective methods in order to achieve final integrated weight factors [20]. The analyzed criteria for all five flotation tailings are shown in Table 4.

Table 4. Presentation of criteria of analyzed flotation ponds.

\begin{tabular}{cc}
\hline Criteria & Analyzed Criteria \\
\hline C1 & Proximity of water source \\
C2 & Proximity of the settlement \\
C3 & Proximity of agricultural area \\
C4 & Proximity of permanent water flow \\
C5 & Quantity of material deposed \\
C6 & Existence of the flooding water sources \\
C7 & Activity of the tailings \\
C8 & Geological environment \\
C9 & General slope of the terrain \\
C10 & Tailing maintenance \\
\hline
\end{tabular}

In order to ascertain the impact ranking of tailing on the local environment, AHP (Analytic Hierarchy Process) and PROMETHEE (Preference Ranking Organization Method for Enrichment Evaluation) are used in this paper. The consideration and description of these two methods from a mathematical aspect is presented briefly considering that these methods are explained in detail in numerous papers [21].

The AHP method is applied for analysis of the decision-making process and solving complex problems, utilizing elements of targets, criteria, sub-criteria and alternatives [22]. The most common application of the AHP method is a result of its ability to identify and analyze inconsistency of the decision makers in the process of validating the hierarchical elements. The variability of this method can be seen in the ability to measure mistakes in the decision-making process, by calculation of the consistency rate. In the papers of Saaty (1986), Alphonce (1997), Harker and Vargas [23-25] the axios for establishing AHP were defined. This method breaks down the complex problems into hierarchy and mutual comparison of their elements. The objective of the investigation is placed at the top of the hierarchy and is not compared with any other elements. On the first level, the criteria are mutually compared in pairs in relation with the first upper tier of the hierarchy Table 5. On the last level of hierarchy, the alternatives are compared in relation to each criterion separately.

Table 5. The Saaty scale.

\begin{tabular}{lcr}
\hline No. & Value of the Category & Description \\
\hline 1 & Same value & Two elements are the same \\
2 & Inter value & Compromise needed, or further division \\
3 & Week dominance & Experience or judgment are in slight favor of one \\
4 & Inter value & Compromise needed, or further division \\
5 & Strong dominance & Experience or judgment are in significant favor of \\
6 & Inter value & one element compared to other \\
7 & Demonstrated value & Compromise needed, or further division \\
8 & Inter value & Compromise needed, or further division \\
9 & Absolute dominance & Dominance of the highest level \\
\hline
\end{tabular}


Every comparison of two elements of the hierarchy (model) is done by using Saaty's scale, expressed by equation [22].

$$
S=\left\{\frac{1}{9}, \frac{1}{8}, \frac{1}{7}, \frac{1}{6}, \frac{1}{5}, \frac{1}{4}, \frac{1}{3}, \frac{1}{2}, 1,2,3,4,5,6,7,8,9\right\}
$$

The basic results of the AHP method are weight criterion rate $(\mathrm{W})$. The weight coefficients are calculated for each element at a certain level. The techniques for the weight coefficient vectors $W$ recommended by Saaty include summarizing the comparison results' matrix rows and normalization of the obtained sums, according to the Equation (2):

$$
\sum_{j=1}^{n} \frac{W_{i}}{W_{j}}=W_{i}\left(\sum_{j=1}^{n} \frac{1}{W_{j}}\right) i=1, \ldots, n
$$

The errors in the process of adding values to the elements in coupling comparison are determined by consistency rate $(C R)$ calculation. In order to calculate the $C R$, the consistency index $(C I)$ should be calculated according to Equation (3):

$$
C I=\frac{\lambda_{\max }-n}{n-1}
$$

where $\lambda_{\max }$ is maximum value of the evaluation matrix. The closer $\lambda_{\max }$ is to the number of alternatives $(n)$, the less inconsistency there is. $\lambda_{\max }$ is calculated by Equation (4):

$$
\lambda_{\max }=\frac{1}{n} \sum_{i=1}^{n} \lambda_{i}
$$

By putting $\lambda_{\max }$ from Equation (3) in Equation (4), the $C I$ is determined. Consistency rate (CR) is the ratio of the consistency index $(C I)$ and random index $(R I)$, according to Equation (5):

$$
C R=\frac{C I}{R I}
$$

Random index $(R I)$ depends on the matrix row, and is taken from Table 6, in which the first row is compared to the matrix row, and the second row is composed of RI.

Table 6. Random Index (RI) [23].

\begin{tabular}{ccccccccccccccc}
\hline $\mathbf{1}$ & $\mathbf{2}$ & $\mathbf{3}$ & $\mathbf{4}$ & $\mathbf{5}$ & $\mathbf{6}$ & $\mathbf{7}$ & $\mathbf{8}$ & $\mathbf{9}$ & $\mathbf{1 0}$ & $\mathbf{1 1}$ & $\mathbf{1 2}$ & $\mathbf{1 3}$ & $\mathbf{1 4}$ & $\mathbf{1 5}$ \\
\hline 0.0 & 0.0 & 0.58 & 0.9 & 1.12 & 1.24 & 1.32 & 1.41 & 1.45 & 1.49 & 1.51 & 1.48 & 1.56 & 1.57 & 1.59 \\
\hline
\end{tabular}

If the consistency rate $(C R)$ is less than 0.1 , the result is consistent and there is no need for changes and calculation repetition. If the consistency rate is higher than 0.1 , the result is considered inconsistent and a partial or complete correction of results, by repeating the double comparison and achieving a satisfactory consistency rate, is needed.

The PROMETHEE method is one of the most important in the field of multi-criteria analysis. This method finds its application in different industrial sectors (mining, chemistry, ecology, medicine, etc.). This allows complete ranking of the alternatives. The method was developed by Jean-Pierre Brans (1982) [26], in two basic versions: PROMETHEE I, a method of partial ranking the alternatives; and PROMETHEE II, a method for complete or combined ranking of alternatives. The most important advantages of this method are its simplicity and that the parameters used have an explanation and meaning. Following elements of ranking are completely eliminated [27]. This method relies on qualitative and quantitative data for each criterion and alternative. The PROMETHEE method introduces preference function $P(a, b)$ for alternatives, $\mathrm{a}$ and $\mathrm{b}$, which are valued by function criterion. 
Alternative $a$ is better than $b$ according to criterion $\mathrm{f}$ if $f(a)<f(b)$ [27]. The value of the preference function is within the interval $[0,1]$, i.e., higher preference is presented by higher function value and vice versa.

The preference function is defined as:

$$
P(a, b)=\left\{\begin{array}{lll}
0, & \text { if } & d \leq 0 \\
1, & \text { if } & d>0
\end{array}\right.
$$

In this case, the following combinations of the function of preference are possible:

$P(a, b)=0$ no preference, indifference;

$P(a, b) \cong 0$ weak preference, $k(a)>k(b)$;

$P(a, b) \cong 1$ strong preference, $k(a)>>k(b)$;

$P(a, b)=1$ tough preference, $k(a)>>>k(b)$.

After that it can be concluded that there are the following two features of the preference function:

- $0 \leq P(a, b) \leq 1$,

- $\quad P(a, b) \neq P(b, a)$.

The basic precondition of the functioning of PROMETHEE is to define the general set of criteria for each individual criterion $k(a)$. There are six types of the general criteria. In creation of the specific model for each type of general criterion, the parameters must be determined. In the next section, the presentations of each individual parameter are given. For the shorter text, the sign $d$ is involved, $d=\mathrm{f}(a)-\mathrm{f}(b)$. According to Brans and Mareschal (1984) [28], there are six types of preference function:

I "Simple" criterion

$$
P(a, b)=\left\{\begin{array}{lll}
0, & \text { if } d \leq q \\
1, & \text { if } d>q
\end{array}\right.
$$

II Quasi criterion

$$
P(a, b)=\left\{\begin{array}{lr}
0, & \text { if } d \leq 0 \\
1, & \text { if } d>q
\end{array}\right.
$$

III Criteria for linear preference

$$
P(a, b)= \begin{cases}0, & \text { if } d \leq 0 \\ \frac{d}{p}, & \text { if } 0<d \leq p \\ 1, & \text { if } d>p\end{cases}
$$

IV Nivoj criterion—stage criterion

$$
P(a, b)= \begin{cases}0, & \text { if } d \leq 0 \\ \frac{1}{2}, & \text { if } 0<d \leq p \\ 1, & \text { if } d>p\end{cases}
$$

V Criterion with linear preference and domain of indifference

$$
P(a, b)=\left\{\begin{array}{c}
0, \text { if } d \leq 0 \\
\frac{d-p}{p-q}, \text { if } 0<d \leq p \\
1, \text { if } d>p
\end{array}\right.
$$


VI Gauss criterion

$$
P(a, b)=\left\{\begin{array}{c}
0, \quad \text { if } \ldots d \leq 0 \\
1-e^{\frac{d^{2}}{2 l f^{2}}} \text { if } \ldots d>q
\end{array}\right.
$$

For the multi-criteria analysis method, PROMETHEE involves preference streams:

$$
\begin{aligned}
\phi_{j}^{+}\left(a_{j}\right) & =\sum_{m=1}^{j} \Pi P\left(a_{j}, a_{m}\right) \text { positive stream } \\
\phi_{j}^{-}\left(a_{j}\right) & =\sum_{m=1}^{j} \Pi P\left(a_{j}, a_{m}\right) \text { negative stream }
\end{aligned}
$$

In general, the higher $\phi_{j}^{+}$, Alternative $a_{j}$ dominates over the other alternatives in the. The higher $\phi_{j}^{-}$, than the other alternatives, however, means further domination over another alternative $a_{j}$ in the system of alternatives. As a measure for multi-criteria evaluation, the PROMETHEE II involves absolute flow:

$$
\phi_{j}\left(a_{j}\right)=\phi_{j}^{+}\left(a_{j}\right)-\phi_{j}^{-}\left(a_{j}\right) ; j=1, \ldots, \mathrm{J}
$$

where $j$ is the number of alternative.

In the analysis conducted in this paper for the PROMETHEE method, the commercial software Visual PROMETHEE 1.4 Academic Edition [29] was used. The PROMETHEE method does not provide us the opportunity to analyze decision making on simpler parts compared to AHP. In cases of a bigger number of criteria, this method makes it harder to come to a conclusion for the analyzed problem [30].

For a more complete graphic presentation of the results obtained by the PROMETHEE method, the GAIA plan (Geometrical Analysis for Interactive Assistance) was used from the software Visual PROMETHEE 1.4 Academic Edition [29]. The basic purpose of this application is better visual presentation of the multi-criteria analysis. In the frame of the GAIA plan, some information can be lost after the projection. Based on the main components, the presentation is defined by two vectors, responding to the basic flow of one criterion. Although GAIA includes some percentage of total information, it does not provide strong graphic support.

\section{Results}

Comparing the influence of certain criteria to the environment was based on relevant data obtained in the field. In Table 1, analyzed criteria which were used as input data for matrix formatting and quantification for coupled comparison of criteria according to the Saaty scale are presented (Table 7). Those data are than included into the calculations by AHP and PROMETHEE methods, by common steps in calculation process.

Table 7. Double comparison matrix of the criteria according to the Saaty scale.

\begin{tabular}{ccccccccccc}
\hline Criteria & C1 & C2 & C3 & C4 & C5 & C6 & C7 & C8 & C9 & C10 \\
\hline C1 & 1 & 1 & 2 & 2 & 5 & 4 & 7 & 5 & 6 & 8 \\
C2 & 1 & 1 & 2 & 2 & 4 & 4 & 5 & 6 & 7 & 8 \\
C3 & $1 / 2$ & $1 / 2$ & 1 & 2 & 5 & 5 & 5 & 6 & 7 & 8 \\
C4 & $1 / 2$ & $1 / 2$ & $1 / 2$ & 1 & 2 & 2 & 5 & 4 & 6 & 7 \\
C5 & $1 / 5$ & $1 / 4$ & $1 / 5$ & $1 / 2$ & 1 & 1 & 5 & 4 & 7 & 6 \\
C6 & $1 / 4$ & $1 / 4$ & $1 / 5$ & $1 / 2$ & 1 & 1 & 5 & 4 & 5 & 6 \\
C7 & $1 / 7$ & $1 / 5$ & $1 / 5$ & $1 / 5$ & $1 / 5$ & $1 / 5$ & 1 & 3 & 3 & 4 \\
C8 & $1 / 5$ & $1 / 6$ & $1 / 6$ & $1 / 4$ & $1 / 4$ & $1 / 4$ & $1 / 3$ & 1 & 3 & 5 \\
C9 & $1 / 6$ & $1 / 7$ & $1 / 7$ & $1 / 6$ & $1 / 7$ & $1 / 5$ & $1 / 3$ & $1 / 3$ & 1 & 2 \\
C10 & $1 / 8$ & $1 / 8$ & $1 / 8$ & $1 / 7$ & $1 / 6$ & $1 / 4$ & $1 / 4$ & $1 / 5$ & $1 / 2$ & 1 \\
\hline
\end{tabular}

Based on results of the calculation done by AHP and PROMETHEE methods, final alternative rank was given—-tailing ponds according to the their negative impact to the environment. 
Matrix with double comparison is formed by AHP method based on previously set criteria (Table 7). Weight coefficients for each criteria are calculated by mutual comparison and based on Saaty's scale (Table 5). Criteria are being added values by direct and inverted procedure in span from 1 to 9 .

By valuing each criterion, coefficient weight of criteria was gained and are shown in Table 8 . For the purpose of control of gained results, calculations of the $C R$ are done. Results obtained confirmed that decision is consistent because its value is less than 0.1 , or its value is 0.082062 (Table 8).

Table 8. Weight coefficient criteria and their level of consistency.

\begin{tabular}{ccc}
\hline Criteria & Coefficient & CR \\
\hline C1 & 0.214389322 & \\
C2 & 0.2083418 & \\
C3 & 0.179621064 & \\
C4 & 0.117821399 & \\
C5 & 0.083593285 & 0.082062 \\
C6 & 0.080421814 & \\
C7 & 0.041623037 & \\
C8 & 0.036710749 & \\
C9 & 0.02131439 & \\
C10 & 0.016163141 & \\
\hline
\end{tabular}

For individual criteria, weight coefficient values, consistency index $(C I)$ and consistency rate $(C R)$ for all five tailings were obtained by the APH method (Table 9). For criterion $\mathrm{C} 1$, the distance of water supply sources, the tailing A3 Žitkovac 0.4740 has the greatest value of weight coefficient, and A4 Tvrđanski Do 0.0715 has the minimum value. For criterion C2, vicinity of settlement, A5 Tvrđanski Do 0.4041 hasthe greatest value of weight coefficient, and A1 Žarkov Potok 0.05546 has the minimum value. For criterion C3 - the vicinity of agricultural environments—-tailing A4 Tvrđanski Do 0.30954 has the greatest value of weight coefficient, and A1 Žarkov Potok 0.0373 has the minimum value. For criterion C4-the vicinity of water stream-the tailing A4 Tvrđanski Do 0.3107 has the greatest value of weight coefficient and A1 Žarkov Potok 0.0837 has the minimum value. For criterion C5-the amount of deposited material-A2 Gornje Polje 0.4851 has the greatest value of weight coefficient, and A4 Tvrđanski Do 0.0420 has the minimum value. For criterion C6-the existence of torrential watercourses, the greatest value of weight coefficient has the tailing A2 Gornje Polje 0.4285, while the remaining tailings have the same value, 0.1428 . For criterion C7, tailing activity, A1 Žarkov Potok and A5 Bostanište 0.3636 both have the greatest value of weight coefficient and the value of the remaining three tailings is 0.0909 . For criterion C8, geology, all tailings have identical weight coefficient which is 0.2. For criterion C9, general slope of a region, A4 Tvrđanski Do and A5 Bostanište 0.2889 have the greatest value of weight coefficient, and the A2 Gornje Polje 0.0723 has the minimum value. For criterion C10-maintenance of tailings—all five tailings have identical value which is 0.2 .

Table 9. Display of maximum values of comparison matrix $(\lambda \max )$, consistency index $(C I)$, random index $(R I)$ and consistency rate $(C R)$ for analyzed tailing ponds.

\begin{tabular}{ccccccccccc}
\hline $\mathbf{C}$ & $\mathbf{C 1}$ & $\mathbf{C 2}$ & $\mathbf{C 3}$ & $\mathbf{C 4}$ & $\mathbf{C 5}$ & $\mathbf{C 6}$ & $\mathbf{C 7}$ & $\mathbf{C 8}$ & $\mathbf{C 9}$ & $\mathbf{C 1 0}$ \\
\hline$\lambda_{\max }$ & 5.08 & 5.46 & 5.12 & 5.46 & 5.34 & 5 & 5 & 5 & 5.04 & 5 \\
$C I$ & 0.02 & 0.11 & 0.03 & 0.11 & 0.08 & 0 & 0 & 0 & 0.01 & 0 \\
$R I$ & 1.12 & 1.12 & 1.12 & 1.12 & 1.12 & 1.12 & 1.12 & 1.12 & 1.12 & 1.12 \\
$C R$ & 0.01 & 0.10 & 0.02 & 0.10 & 0.07 & 0 & 0 & 0 & 0.01 & 0 \\
\hline \multicolumn{8}{c}{ C-criteria; P-parameter. }
\end{tabular}


According to the conducted estimation with the application of the AHP method, the criterion C1, distance from the source of water supply, 0.2143 , has the greatest value of weight coefficient and the criterion C10-maintenance of tailings, 0.0162 - has the minimum value.

Alternatives have been evaluated and a quantified matrix of decision making has been formed (Table 10) by application of the PROMETHEE method for evaluation of environmental influence of tailing ponds. In this process, certain criteria have a quantitative structure, while others are qualitative. Consequently, certain criteria $(\mathrm{C} 1, \mathrm{C} 2, \mathrm{C} 3, \mathrm{C} 4, \mathrm{C} 5, \mathrm{C} 8, \mathrm{C} 9)$ are stated quantitatively, while others are stated qualitatively. The application of qualitative and quantitative scales provides confidence that all criteria are well arranged in the best manner possible.

Table 10. Quantified matrix of decision making (Evaluation matrix).

\begin{tabular}{|c|c|c|c|c|c|c|c|c|c|c|}
\hline Criteria & $\mathrm{C} 1$ & $\mathrm{C} 2$ & $\mathrm{C} 3$ & $\mathrm{C} 4$ & C5 & C6 & $\mathrm{C} 7$ & $\mathrm{C} 8$ & C9 & $\mathrm{C} 10$ \\
\hline $\operatorname{Max} / \min$ & Min & Min & Min & Min & Max & Max & Max & Min & Max & Min \\
\hline Preference function & Linear & Linear & Linear & Linear & V shape & Level & Level & Linear & Linear & Level \\
\hline $\mathrm{A} 1$ & 0 & 500 & 500 & 100 & $9,961,113$ & No & Yes & 4 & 12 & No \\
\hline $\mathrm{A} 2$ & 50 & 200 & 200 & 50 & $2,634,421$ & Yes & No & 4 & 0 & No \\
\hline A5 & 1200 & 50 & 50 & 70 & $5,641,612$ & No & Yes & 4 & 10 & No \\
\hline
\end{tabular}

After quantified matrix of decision making was provided, analyzed alternatives (tailing ponds) were evaluated using Visual PROMETHEE software. This resulted with a rank order of alternatives. Multi-criteria ranking method PROMETHEE introduces qualities of positive, negative and net flow [29]. The results obtained from positive, negative and net flow are presented in Table 11.

Table 11. PROMETHEE flows.

\begin{tabular}{cccc}
\hline Alternatives & $\mathbf{P h}+$ & $\mathbf{P h}-$ & $\mathbf{P h}$ \\
\hline A1 & 0.4019 & 0.2155 & 0.1864 \\
A2 & 0.3157 & 0.2496 & 0.0661 \\
A3 & 0.3071 & 0.3172 & -0.0100 \\
A4 & 0.3467 & 0.3606 & -0.0140 \\
A5 & 0.2983 & 0.5268 & -0.2284 \\
\hline
\end{tabular}

\section{Discussion}

In recent years, as a part of the numerous activities of MMCC "Trepča", five tailing ponds were formed in this area, receiving a significant amount of disposed material from the category of pollutants that are potentially dangerous to the surrounding ecosystem. The tailing ponds are unsuitably placed and the current lack of maintenance in addition to the disposed materials can permanently endanger the living environment. At the same time, these ponds represent a potential danger which can reach the category of ecological disasters.

Numerous activities of the local population are taking place in relatively close proximity to these tailing ponds, despite the very precarious situation. Often, the local population has created facilities and taken part in activities, which are not safe so close to tailing ponds. For example, at about $50 \mathrm{~m}$ from some landfills there are wells used for irrigation and water supply, while some fields and streams are also only $50 \mathrm{~m}$ away from some landfills. Generally, all of the five treated tailings were formed in places that can have harmful effects on the surrounding ecosystem. The situation described here was meant to conduct an analysis and ranking of the tailings by the degree of potential danger to the living environment.

The ranking of the analyzed alternatives is given in Figures 3-5 using the PROMETHEE method. 


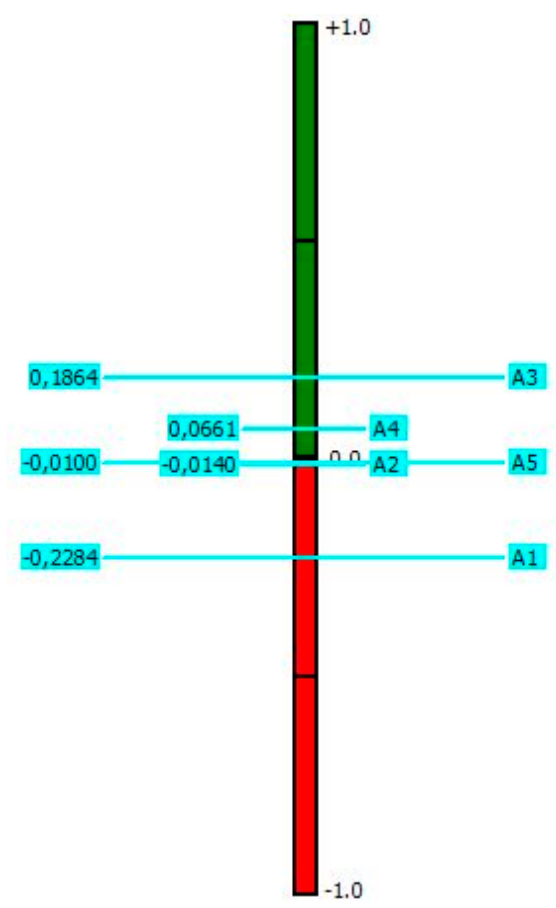

Figure 3. Final ranking. Tailings-A1-Žarkov Potok; A2-Gornje Polje; A3-Žitkovac; A4-Tvrđanski Do; A5-Bostanište.

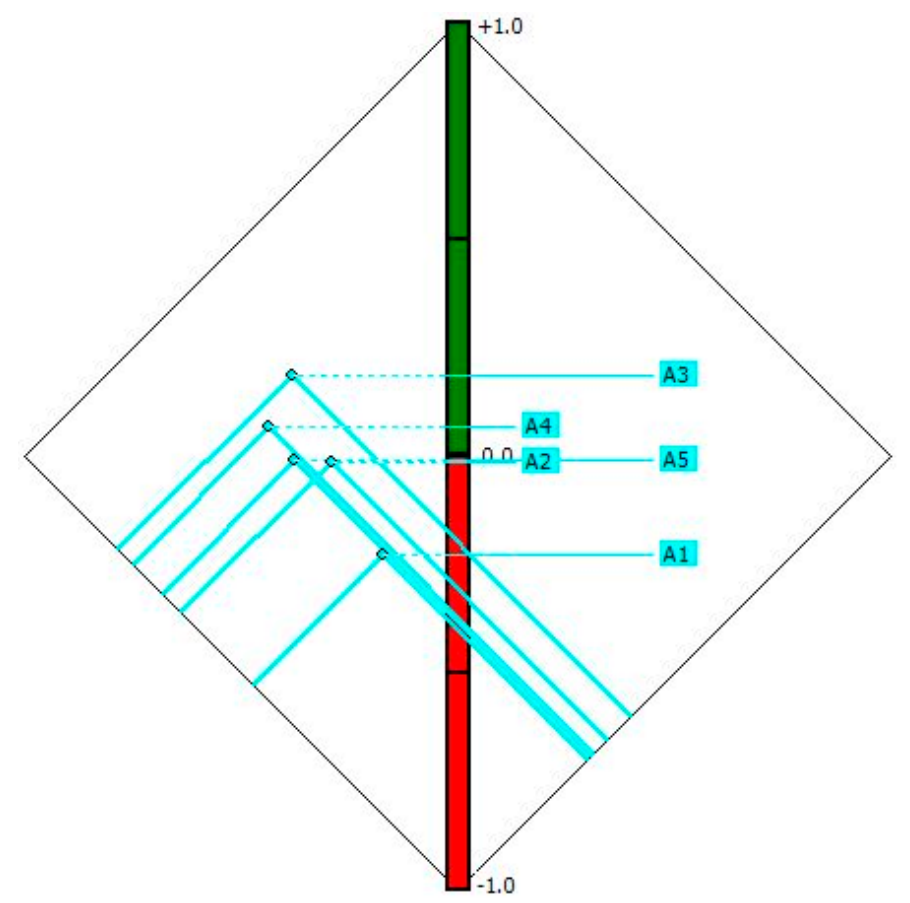

Figure 4. PROMETHEE diamond solutions. Tailings-A1-Žarkov Potok; A2-Gornje Polje; A3-Žitkovac; A4-Tvrđanski Do; A5-Bostanište. 


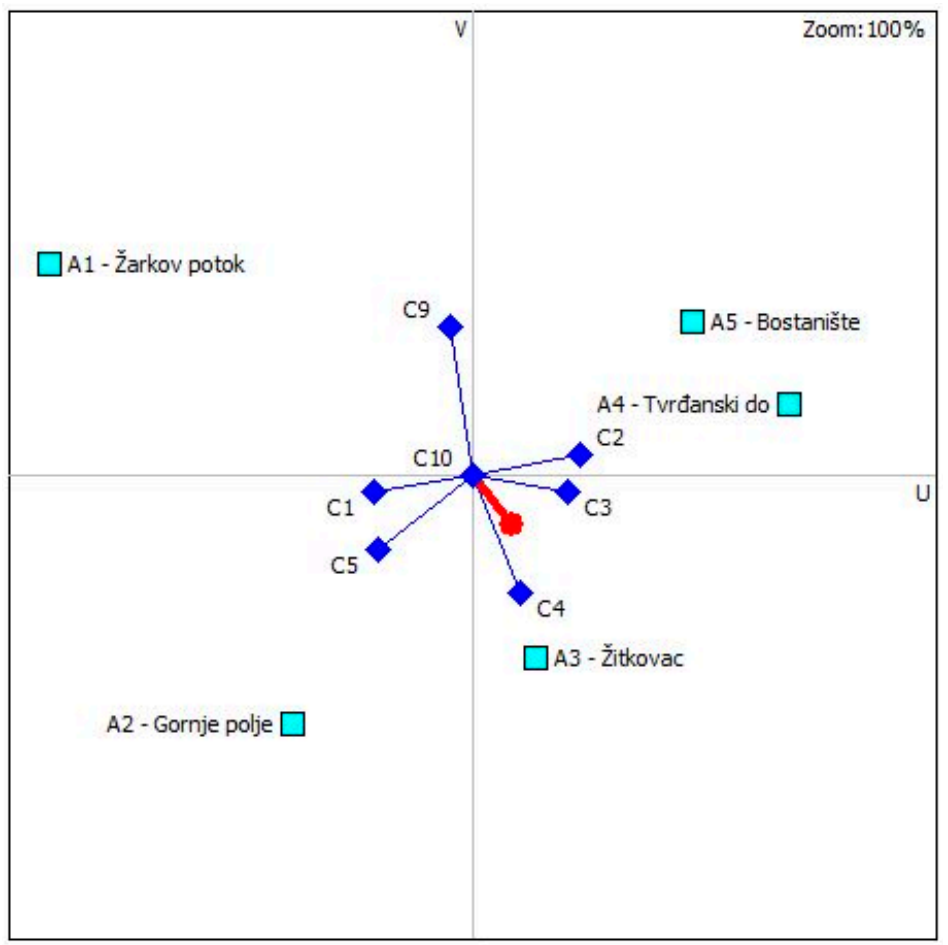

Figure 5. GAIA plan for tailing ponds.

In Figure 3, the final ranking of analyzed tailing ponds is given. This figure is based on net flow Phi. The upper half of the given scale (colored in green) represents positive Phi value, and the lower half (red) represents negative Phi value. Alternative A3 (Žitkovac) is at the top of the analyzed alternatives, preceding A4 (Tvrđanski Do), while A2 (Gornje Polje) and A5 (Bostanište) are about the same negative Phi values. At the bottom of the list is the alternative A1 (Žarkov Potok). Values of the Phi flow for these alternatives are given in Figure 3.

Figure 4 shows a diamond PROMETHEE solution. This solution shows partial PROMETHEE I and final ranking PROMETHEE II in a two-dimensional model. The PROMETHEE diamond solution is presented with the dot on (Phi+,Phi-) flat. The flat is at an angle of $45^{\circ}$ so that the vertical dimension (red-green axis) corresponds to Phi net flow. A cone is drawn for every alternative. Cones A2 and A5 overlap, which indicates that these two alternatives are closely congruent, while the alternative A2 has the advantage in partial ranking PROMETHEE I. The highest priority alternative is A3 (Žitkovac), and the lowest is alternative A1 (Žarkov Potok).

In Figure 5, the GAIA plan is shown (Geometrical Analysis for Interactive Assistance), which is a descriptive addition to the PROMETHEE ranking. Every alternative is presented with a dot found on the GAIA plan. The position of these alternatives is connected with the marks of a set of criteria. Each criterion is presented with the axis from the center of the GAIA plan. The orientation of these axes shows how these criteria are interrelated. Alternative A4 and A5 are similar because they are closer to each other, whereas the other alternatives are completely dissimilar. Criteria with similar preferences are $\mathrm{C} 5, \mathrm{C} 1$ and $\mathrm{C} 2$ and $\mathrm{C} 3$, conflicting criteria are $\mathrm{C} 9$ and $\mathrm{C} 4$. The determination axis (red axis) suggests the alternative A3 tailing Žitkovac has the least favourable impact on the surrounding ecosystem.

With implementation of estimation by using the AHP and PROMETHEE methods, with the aim of ranking the impact on the environment, the ranks are obtained according to their negative impact (Table 12). The comparative analysis of the negative impact on the surrounding ecosystem shows that the least favorable tailing pond is A3 Žitkovac, and that the least negative impact has the alternative A1 Žarkov Potok. Three remaining tailings have the following order of unfavorable impact on the environment: A4 Tvrđanski Do, A5 Bostanište and A2 Gornje Polje. 
Table 12. The rank of solutions according to the AHP and PROMETHEE methods.

\begin{tabular}{ccc}
\hline Rank & AHP & PROMETHEE \\
\hline A3-Žitkovac & 1 & 1 \\
A4-Tvrđanski Do & 2 & 2 \\
A5-Bostanište & 3 & 3 \\
A2-Gornje Polje & 4 & 4 \\
A1-Žarkov Potok & 5 & 5 \\
\hline
\end{tabular}

It should be noted that other methods of multi-criteria analysis (VIKOR, TOPSIS, ELECTRE) also should be used to verify the results and the final decision.

Finally, it should be emphasized that the legal regulations relevant for MMCC "Trepča" in terms of environmental protection can be classified into three levels: (1) Constitution (RS Official Gazette, No. 98/2006) [31], International Conventions (Directive 98/83/EC: Quality of water intended for human consumption, Directive Drinking Water [32]; Directive 80/68/EEC: Protection of groundwater against pollution caused by certain dangerous substances [33]; Directive 93/67/EEC: Risk Assessment for new notified substances [34]; Directive 86/278/EEC: Protection of the environment, and in particular of the soil, when sewage sludge is used in agriculture [35]) and Recommendations; (2) By-Laws on Environmental Protection (RS Official Gazette, No. 36/2009) [36]; Law on Nature Protection (RS Official Gazette, No. 88/2010) [37]; Law on Mining and Geological Surveys (RS Official Gazette, No. 101/2015) (In Serbian) [38], Water Law (RS Official Gazette, No. 93/2012) [39]; (3) By-laws, regulations, instructions, directives regulation on the threshold values of pollutants in surface waters, groundwater and sediment and deadlines for their achievement (2012) (RS Official Gazette, No. 50/2012) [40]. Unanimous compliance with the Constitution of the Republic of Serbia is mandatory; the application of the International Conventions and Recommendations relevant to the mining industry and environmental protection should enable the fulfilment of the requirements related to the environmental protection valid for all members of the EU.

\section{Conclusions}

This paper analyzed and ranked the impact on the surrounding ecosystem of five flotation tailings which are in the MMCC "Trepča," located to the north of Kosovo and Metohija. The analysis was conducted for the following tailings: Žarkov Potok, Gornje Polje, Žitkovac, Tvrđanski Do and Bostanište. Tailings have a very strong impact on the surrounding ecosystem, considering the chemical composition of the deposited tailings, as well as where the tailings that are not repaired are located. These tailings are a major source of pollution in these areas of natural beauty and historical significance.

The result obtained using multi-criteria analysis ranking the impact on the environment of five analyzed tailing ponds with the application of the AHP and PROMETHEE methods showed a certain reality, which is in accordance with the situation on the terrain. According to this analysis, the most problematic tailing pond is Žitkovac, and then Tvrđanski Do, Bostanište, Gornje Polje and finally Žarkov Potok. Application of the results can be used in the decision-making process for prioritizing the rehabilitation of the tailings.

The application of the method for the multi-criteria analysis of the impact of pollutants on the environment should be an integral part of the overall management system to the highest level as the enforcement of environmental protection is an interactive process. In the case of the MMCC "Trepča," the possibility of a method for multi-criteria analysis is demonstrated in the field of analysis and ranking of the influence tailing ponds have on the surrounding ecosystem.

Because of its primary purpose which is excavation and processing of mineral resources, MMCC "Trepča" should be more focused on increased concern about environmental protection. MMCC "Trepca" is required to identify and to abide legal requirements of its activity concerning environmental protection. This also applies to international laws, as well as national, regional, provincial and 
municipal. Where laws and regulations are not sufficient to meet the needs, MMCC "Trepča" can establish its own internal criteria.

Acknowledgments: The research presented in this paper was conducted as a part of the Project III 43007: Climate Change Impact to the Environment-Assessment, Adaptation and Mitigation, Sub-Project 15: Climate Change Impact to the Environment and Natural Resources of the North of Kosovo and Metohija and Project OI 176018: Geological and ecotoxicological investigations in identification of geopathogenic zones of toxic elements in the reservoirs of drinking water supported by the Ministry of Education, Science and Technological Development of the Republic of Serbia.

Author Contributions: In this paper, the authors Gordana Milentijević, Blagoje Nedeljković, and Jelena Dokić was provided by research in the field. They also perform analysis and display characteristics of tailings from processing of flotation of metallic mineral ores from MMCC "Trepča" mining activities. The authors Milena Lekić, Zoran Nikić and Ivica Ristović have applied AHP (Analytic Hierarchy Process) and PROMETHEE (Preference Ranking Organization Method for Enrichment Evaluation) methods in order to ascertain the impact ranking of tailings from processing of flotation of metallic mineral ores on the local environment.

Conflicts of Interest: The authors declare no conflict of interest.

\section{References}

1. Ristović, I.; Stojaković, M.; Vulić, M. Recultivation and Sustainable Development of Coal Mining in Kolubara Basin. Therm. Sci. 2010, 14, 759-772. [CrossRef]

2. Stevanović, B.; Knežević, L.; Čikarić, S.; Popov-Ilić, G.; Karaman, G.; Nedović, B.; Todić, D.; Vukasović, V.; Vujošević, M.; Stojanović, B.; et al. Enciklopedija-Životna Sredina i Održivi Razvoj-Knjiga Tačnih Odgovora. ECOLIBRI; Zavod za udžbenike i nastavna sredstva: Srpsko Sarajevo, Bosnia and Herzegovina, 2003.

3. Commission of the European Communities. Proposal for a Directive of the European Parliament and of the Council on the Management of Waste from Extractive Industries; Commission of the European Communities: Brussels, Belgium, 2003.

4. Ewell, M. 2012 Minerals Yearbook: Mining and Quarrying Trends; U.S. Geological Survey: Reston, VA, USA, 2014.

5. Ministarstvo nauke i zaštite životne sredine. Izveštaj o stanju životne sredine u Republici Srbiji 2003. i 2004; Agencija za zaštitu životne sredine: Beograd, Srbija, 2005.

6. Kamberović, Ž.; Radović, N.; Korać, N.; Jovanović, M. Strategija Uvođenja Čistije Proizvodnje u Metalurgiju Republike Srbije. Zbornik Radova II Simpozijuma: "Reciklažne Tehnologije i Održiv Razvoj"; Univerzitet u Beogradu, Tehnički fakultet u Boru: Sokobanja, Srbija, 2007; pp. 284-291.

7. Bogdanović, D.; Nikolić, D.; Ilić, I. Mining method selection by integrated AHP and PROMETHEE method. An. Aced. Bras. Cienc. 2012, 84, 219-233. [CrossRef]

8. Ataei, M.; Jamshidi, M.; Sereshki, F.; Jalali, S.M.E. Mining method selection by AHP Approach. J. S. Afr. Inst. Min. Metall. 2008, 108, 741-749.

9. Kiker, G.; Bridges, T.S.; Varghese, A.; Seager, T.P.; Linkovjj, I. Application of Multicriteria Decision Analysis in Environmental Decision Making. Integr. Environ. Assess. Manag. 2005, 1, 95-108. [CrossRef] [PubMed]

10. Radovanović, D.; Srečković-Batoćanin, D.; Ivanović, R.; Valjarević, A. Uticaj Fizičko Geografskih Faktora na Intezitet Erozije u Rečnim Slivovima Kosova i Metohije; Univerzitet u Prištini, Prirodno-matematički fakultet: Kosovska Mitrovica, Srbija, 2012; pp. 1-175.

11. Nedeljković, B.; Milentijević, G.; Lazić, M. Zaštita životne sredine u neaktivnim industrijskim područjima. In Proceedings of the Zbornik radova "Zaštita životne sredine u industrijskim područjima", Kosovska Mitrovica, Srbija, 19-20 April 2007; pp. 8-25.

12. Nikić, Z. Hydrogeological Analysis of the Low Flows Formation and Regionalization; Zadužbina Andrejević: Belgrade, Serbia, 2003; pp. 1-154.

13. Milentijević, G. Podzemne Vode Severnog Dela Kosova i Metohije-Iskorišćavanje i Zaštita. Ph.D. Thesis, Univerzitet u Beogradu Rudarsko-geološki fakultet, Beograd, Serbia, 2005.

14. Milentijević, G.; Nedeljković, B.; Ristović, I. Analiza uticaja rada MMCC “Trepča” na zagađivanje voda reke Ibar teškim metalima na području Zvečana. In Proceedings of the Zbornik radova III Međunarodnog Simpozijuma “Energetsko rudarstvo 2010", Apatin, Srbija, 8-11 September 2010; pp. 141-147. 
15. Milentijević, G.; Djokić, J.; Nedeljkovic, B. Exploring Possibilities for Tailing Waste Deposit Management. In Proceedings of the International Conference: The Role of Business in Sustainable Development in the Western Balkans, Kosovo, Serbia, 15-16 September 2015.

16. “Sl. glasnik RS", br. 50/2012. Uredba o graničnim vrednostima zagađujućih materija u površinskim i podzemnim vodama i sedimentu i rokovima za njihovo dostizanje. Available online: http://www.slglasnik. com/ (accessed on 24 August 2016).

17. Barać, N. Katakterizacija Flotacijske Deponije “Bostanište” I Njen Uticaj Na Životnu Sredinu. Bachelor's Thesis, Univerzitet u Prištini, Kosovska Mitrovica, Serbia, 12 October 2009.

18. “Sl. glasnik RS”, br. 88/2010. Uredba o programnu sistematskog praćenja kvalietat zemljišta, indikatorima za ocenu rizika od degradacije zemljišta i metodologiji za izradu remedijacionih programa. Available online: http:/ /www.slglasnik.com/ (accessed on 24 August 2016).

19. Milentijević, G.; Spalević, Ž.; Bjelajac, Ž.; Đokić, J.; Nedeljković, B. Impact Analysis of Mining Company "Trepča" to the Contamination of the River Ibar Water, National vs. European Law Regulations. Metal. Int. 2013, 18, 283-288.

20. Agarski, B. Razvoj Sistema za Inteligentnu Višekriterijumsku Procenu Opterećenja Životne Sredine Kod Ocenjivanja Ciklusa Proizvoda i Procesa. Ph.D Thesis, Univerzitet u Novom Sadu, Novi Sad, Srbija, 2014.

21. Nikolić, M. Metode Odlučivanja; Univerzitet u Novom Sadu, Tehnički fakultet “Mihajlo Pupin”: Zrenjanin, Srbija, 2009.

22. Saaty, T. The Analytical Hierarchy Process; Mc-Graw-Hill: New York, NY, USA, 1980.

23. Saaty, T. Axiomatic foundation of the analytic hierarchy process. Manag. Sci. 1986, 32, 841-855. [CrossRef]

24. Alphonce, C.B. Application of the Analytic Hierarchy Process in Agriculture in Developing Countries. Agric. Syst. 1997, 53, 97-112. [CrossRef]

25. Harker, P.T.; Vargas, L.G. The theory of ratio scale estimation: Saaty's Analytic hierarchy process. Manag. Sci. 1987, 33, 1383-1403. [CrossRef]

26. Brans, J.-P. L'ingénièrie de la décision; Elaboration d'instruments d'aide à la décision. La méthode PROMETHEE. In L'aide à la Décision: Nature, Instruments et Perspectives d'Avenir; Nadeau, R., Landry, M., Eds.; Presses de l’Université Laval: Ville de Québec, QC, Canada, 1982; pp. 183-213.

27. Albadvi, A.; Chaharsooghi, S.K.; Esfahanipour, A. Decision making in stock trading: An application of PROMETHEE. Eur. J. Oper. Res. 2007, 177, 673-683. [CrossRef]

28. Brans, J.-P.; Mareschal, B. PROMETHEE: A new family of outranking methods in multicriteria analysis. Oper. Res. 1984, 84, 163-195.

29. Visual PROMETHEE 1.4 Manual, 5 September 2013. Available online: http:/ /www.promethee-gaia.net/ (accessed on 12 April 2016).

30. Macharis, C.; Springael, J.; De Brucker, K.; Verbeke, A. PROMETHEE and AHP: The design of operational synergies in multicriteria analysis. Strengthening PROMETHEE with ideas of AHP. Eur. J. Oper. Res. 2004, 153, 307-317. [CrossRef]

31. RS Official Gazette, No 98/2006: Constitution of the Republic of Serbia. Available online: http://www. slglasnik.com/ (accessed on 25 August 2016.).

32. Council Directive 98/83/EC of 3 November 1998 on the Quality of Water Intended for Human Consumption, Directive Drinking Water. Available online: http://eur-lex.europa.eu/legal-content/EN/TXT/?uri= CELEX\%3A31998L0083 (accessed on 25 August 2016).

33. Council Directive 80/68/EEC of 17 December 1979 on the Protection of Groundwater against Pollution Caused by Certain Dangerous Substances. Available online: http:/ /eur-lex.europa.eu/legal-content/EN/ TXT/?uri=CELEX\%3A31980L0068 (accessed on 25 August 2016).

34. Commission Directive 93/67/EEC on Risk Assessment for New Notified Substances. Available online: http://eur-lex.europa.eu/legal-content/EN/TXT/?uri=CELEX\%3A31993L0067 (accessed on 25 August 2016).

35. Council Directive 86/278/EEC of 12 June 1986 on the Protection of the Environment, and in Particular of the Soil, When Sewage Sludge is Used in Agriculture. Available online: http:/ /eur-lex.europa.eu/legalcontent/EN/TXT/?uri=celex\%3A31986L0278 (accessed on 25 August 2016).

36. RS Official Gazette, No. 135/2004, 36/2009: Law on Environmental Protection. Available online: http://www.slglasnik.com/ (accessed on 22 August 2016). (In Serbian) 
37. RS Official Gazette, No. 36/2009, 88/2010: Law on Nature Protection. Available online: http://www. slglasnik.com/ (accessed on 22 August 2016). (In Serbian)

38. RS Official Gazette, No. 101/2015: Law on Mining and Geological Surveys. Available online: http://www. slglasnik.com/ (accessed on 22 August 2016). (In Serbian)

39. RS Official Gazette, No. 30/2010, 93/2012: Water Law. Available online: http://www.slglasnik.com/ (accessed on 24 August 2016). (In Serbian)

40. RS Official Gazette, No. 50/2012: Regulation on the Threshold Values of Pollutants in Surface Waters, Groundwater and Sediment and Deadlines for Their Achievement. Available online: http://www.slglasnik. com/ (accessed on 22 August 2016). (In Serbian)

(C) 2016 by the authors; licensee MDPI, Basel, Switzerland. This article is an open access article distributed under the terms and conditions of the Creative Commons Attribution (CC-BY) license (http://creativecommons.org/licenses/by/4.0/). 